\title{
Isorhynchophylline alleviates learning and memory impairments induced by aluminum chloride in mice
}

\author{
Hui-Qin Li ${ }^{1}$, Siu-Po Ip ${ }^{1,2}$, Guo-Qing Zheng ${ }^{3}$, Yan-Fang Xian ${ }^{1,2^{*}}$ and Zhi-Xiu Lin ${ }^{1,2,4^{*}}$
}

\begin{abstract}
Background: To evaluate the effect of Isorhynchophylline (IRN) on the learning and memory impairments induced by aluminum chloride $\left(\mathrm{AlCl}_{3}\right)$ in mice.

Methods: Fifty male Balb-c mice (4-month-old) were randomly divided into five groups: control, $\mathrm{AlCl}_{3}$ plus vehicle, $\mathrm{AlCl}_{3}$ plus IRN $(20 \mathrm{mg} / \mathrm{kg}), \mathrm{AlCl}_{3}$ plus IRN $(40 \mathrm{mg} / \mathrm{kg})$ and $\mathrm{AlCl}_{3}$ plus donepezil $(5 \mathrm{mg} / \mathrm{kg})$. Learning and memory impairments were induced in mice by subcutaneously injecting with $\mathrm{AlCl}_{3}(50 \mathrm{mg} / \mathrm{kg})$ once a day for 8 consecutive weeks. At the same time, mice were intragastrically given vehicle or IRN (20 and $40 \mathrm{mg} / \mathrm{kg}$ ) or donepezil $(5 \mathrm{mg} / \mathrm{kg}) 30 \mathrm{~min}$ before each $\mathrm{AlCl}_{3}$ injection. The spatial learning and memory function was assessed using radial arm maze. After sacrificed, the parameters of oxidative stress and cholinergic system in the brain tissues were examined with ELISA kits. Moreover, the expression of nuclear factor kappa B (NF-KB) signaling pathway was analyzed with western blotting.

Results: The results showed that treatment with IRN could significantly ameliorate the cognitive deficits induced by $\mathrm{AlCl}_{3}$ in mice. In addition, treatment with IRN was found to reduce the level of malondialdehyde, enhance the activities of superoxide dismutases and catalase, increase the level of glutathione, and markedly inhibit the activity of acetylcholinesterase (AChE) in the brain tissues of the $\mathrm{AlCl}_{3}$-treated mice. Moreover, IRN significantly suppressed the phosphorylation of NF-KB p65 and IKBa in the brain tissues of $\mathrm{AlCl}_{3}$-treated mice. However, IRN did not show significant effect on the activity of butyrylcholinesterase.

Conclusion: Our findings demonstrated for the first time that IRN could alleviate learning and memory impairments induced by $\mathrm{AlCl}_{3}$ in mice. The neuroprotective effect of IRN against $\mathrm{AlCl}_{3}$-induced $\mathrm{AD}$ is probably mediated, at least in part, through inhibiting the AChE activity and reducing the oxidative damage of brain tissue via suppress the NF-kB signaling pathway. These results contributed to a better understanding of the in vivo anti-AD mechanism of IRN. It was concluded that IRN could protect the learning and memory function.
\end{abstract}

Keywords: Isorhynchophylline, Aluminum chloride, Learning and memory impairments, Oxidative stress, Cholinergic system, Nuclear factor kappa B pathway

\section{Background}

Alzheimer's disease (AD) is a neurodegenerative disease characterized by progressive memory dysfunction and cognitive deficiency [1]. As the world's population ages, we face a looming global epidemic of AD; and by 2050 the number of $\mathrm{AD}$ patients is estimated to be 106.4 million

\footnotetext{
*Correspondence: lisaxian@cuhk.edu.hk; linzx@cuhk.edu.hk

${ }^{1}$ School of Chinese Medicine, Faculty of Medicine, The Chinese University

of Hong Kong, Hong Kong, SAR, People's Republic of China

Full list of author information is available at the end of the article
}

globally [2]. Although beta-amyloid (A $\beta)$ accumulation and tau protein malformation are generally accepted to be the causal factors of AD, the cellular and molecular pathology and etiology of AD have not been fully understood, largely due to the fact that $\mathrm{AD}$ is a multifactorial disease involving genetic, epigenetic, and environmental factors [3]. Furthermore, present treatments available for $\mathrm{AD}$ are usually limited to symptomatic management, and no satisfactory therapeutic agents are available for $\mathrm{AD}$ patients [4-6]. Thus, novel therapies with better efficacy 
and safety profiles are urgently needed to modify the natural history of AD.

Aluminum, which can cross the blood brain barrier (BBB) [7], is a well-known neurotoxin that has close association with AD pathogenesis [8]. Based on the studies on the hippocampal neurons of $\mathrm{AD}$ patients, aluminum was found to be involved in the formation of neurofibrillary tangles in neurons, and therefore considered as a causative factor for AD [9]. Moreover, studies have also shown that exposure to aluminum can cause memory impairment in animal models $[10,11]$. The underlying mechanisms for aluminum to induce AD-like behaviors are believed to involve oxidative damage [11], formation of hyperphosphorylated tau [12], aggregation of amyloid beta protein [13], increase in AChE activity [14] and neuronal apoptosis [13]. In addition to neuronal dysfunction, aluminum could also lead to brain dysfunction via glial alterations [15]. Given that aluminum exposure could eventually result in neuropathological and neurobehavioral changes, and impaired learning and memory, $\mathrm{AlCl}_{3}$-induced model is therefore used as an established $\mathrm{AD}$ animal model and often used for testing the efficacy of therapeutic agents for AD.

Uncaria rhynchophylla is a component herb of many popular herbal formulae commonly prescribed for the treatment of $\mathrm{AD}[16,17]$. Recently, many studies have showed that ethanol extract of $U$. rhynchophylla has neuroprotective effect on different in vivo and in vitro $A D$ models $[18,19]$. Isorhynchophylline (IRN, the chemical structure is shown in Fig. 1), a c-22 oxindole alkaloid richly presented in the ethanol extract of $U$. rhynchophylla, is the main active chemical ingredient for its biological activities [20]. Our previous studies revealed that IRN could ameliorate the neurotoxicity induced by $A \beta_{25-}$ 35 on PC12 cells via PI3K/Akt/GSK-3 $\beta$ signaling pathway [21], improve the memory deficits induced by $A \beta_{25-35}$ in rats via inhibition of neuronal apoptosis and tau protein hyperphosphorylation [22], and reduce the memory deficits induced by D-galactose in mice through enhancing the antioxidant status and anti-inflammatory effect in brain tissues via nuclear factor kappa B (NF- $\mathrm{kB}$ ) signaling pathway [23]. Moreover, it was found that the $\mathrm{LD}_{50}$ values of IRN in mice are about 510, 217 and $80 \mathrm{mg} / \mathrm{kg}$, respectively, with oral, intraperitoneal and intravenous administration, indicating that IRN is at least 10 times less toxic than other known anti-AD drugs, and is a safer chemical compound for AD treatment [24]. All these studies implied that IRN is a promising neuroprotective agent for AD treatment warranting further investigation. However, whether IRN has therapeutic effect on $\mathrm{AlCl}_{3}$-treated mice and the underlying mechanisms have not been studied yet. The present study aimed to investigate the neuroprotective effects of IRN on cognitive function in

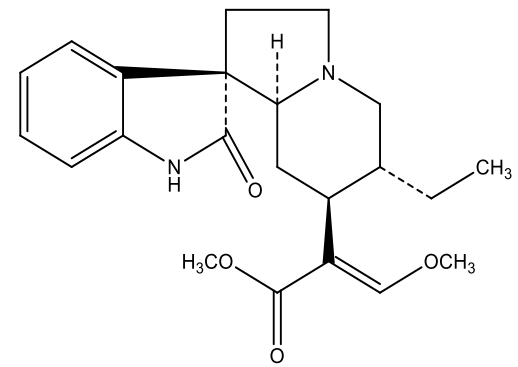

Fig. 1 Chemical structure of isorhynchophylline (IRN)

the $\mathrm{AlCl}_{3}$-treated mice and to elucidate the underlying mechanisms of action.

\section{Methods}

The minimum standards of reporting checklist (Additional file 1) contains details of the experimental design, statistics, and resources used in this study.

\section{Drugs and reagents}

Isorhynchophylline (IRN, purity $\geq 98 \%$ ) was purchased from Chengdu Mansite Pharmaceutical Co. Ltd. (Chengdu, Sichuan, China). Aluminum chloride hexahydrate $\left(\mathrm{AlCl}_{3}\right)$ and donepezil hydrochloride (referred to simply as donepezil thereafter) were purchased from Sigma-Aldrich (St. Louis, MO, USA). All other reagents and chemicals used in the study were of analytical grade.

\section{Animals}

Fifty male Balb-c mice (4-month-old, weighing 25-30 g) were obtained from the Laboratory Animal Services Center, The Chinese University of Hong Kong. The animals were maintained on a $12 \mathrm{~h}$ light/dark cycle under controlled temperature $\left(22 \pm 2{ }^{\circ} \mathrm{C}\right)$ and humidity $(50 \pm 10 \%)$, and given standard diet and water ad libitum.

\section{Animal groupings and drug treatment}

The mice were randomly assigned into five groups of 10 animals each: (a) control; (b) $\mathrm{AlCl}_{3}$ plus vehicle; (c) and (d) $\mathrm{AlCl}_{3}$ plus IRN (20 and $40 \mathrm{mg} / \mathrm{kg}$ ); and (e) $\mathrm{AlCl}_{3}$ plus donepezil $(5 \mathrm{mg} / \mathrm{kg})$, which was used as the positive control [22]. The dosages of IRN were selected based on our previous studies $[22,23] . \mathrm{AlCl}_{3}$ was dissolved in sterile physiological saline at the concentration of $5 \mathrm{mg} / \mathrm{mL}$, and subcutaneously injected into the mice at a dosage of $50 \mathrm{mg} / \mathrm{kg}$ once a day for 8 consecutive weeks before the behavioral assessments were started. The duration and dosage of aluminum was selected based on the previous published studies with minor modification [25]. In the control group, mice were subjected to the same injection schedule except using physiological saline instead 
of $\mathrm{AlCl}_{3}$. At the same time, IRN and donepezil were suspended in $0.5 \%$ sodium carboxymethyl cellulose (CMC$\mathrm{Na}$ ), then given to the mice intragastrically daily $30 \mathrm{~min}$ before each $\mathrm{AlCl}_{3}$ injection, while the control group and $\mathrm{AlCl}_{3}$ plus vehicle control group were given the same volume of $0.5 \% \mathrm{CMC}-\mathrm{Na}$. Behavioral assessments were carried out after the $\mathrm{AlCl}_{3}$ injection was finished. During the behavioral assessment, the treatment was ongoing until the working and reference memory tasks test, which was undertaken at day 64. Detailed experimental schedules were depicted in Fig. 2.

\section{Radial arm maze (RAM) test}

Spatial learning and memory changes in mice were determined by the RAM test. A modular radial arm maze with SuperMaze V2.0 video tracking software (Shanghai Xinruan Information Technology Co. Ltd, Shanghai, China) was used for this experiment. The maze consisted of eight arms, numbered from 1 to 8 (35 cm long, $5 \mathrm{~cm}$ wide and $10 \mathrm{~cm}$ high), extending radially from a central platform (22 cm in diameter). The radial arm maze test was conducted as described previously with minor modifications [26, 27]. In the room, several visual extra-maze cues were provided close $(10-30 \mathrm{~cm})$ to the maze in a fixed configuration. A circular food well $(1 \mathrm{~cm}$ in diameter, $0.5 \mathrm{~cm}$ deep) was positioned at the end of each arm. During behavioral training and testing, to stimulate hunger, the animals were kept on restricted diet with only water being available ad libitum and the body weight was maintained at about $85-90 \%$ of their free-feeding level. Initially, animals received two $10 \mathrm{~min}$ habituation trials, $24 \mathrm{~h}$ apart, with free access to all arms on the first 2 days. At the beginning of each habituation trial, three or four mice were simultaneously placed in the central platform and all arms were baited with several approximately $10 \mathrm{mg}$ food pellets. Then, mice were trained for
5 consecutive days, one trial per day, to run to the end of the arms and consume the bait. At the beginning of each training trial, only one mouse was placed in the central platform and only four constant arms were randomly selected and baited with one approximately $10 \mathrm{mg}$ food pellet, which was placed in a food cup that prevented visual detection. A trial was ended when all the four baits had been consumed or after a maximum of $10 \mathrm{~min}$ had elapsed. An arm entry was counted when all four limbs of the mice were within an arm. At the eighth day, the mice were subjected to working and reference memory tasks, in which the same four arms were baited as each daily training trial, and the following behavioural measurements were recorded: (1) number of reference memory errors (RMEs), i.e. entries into a non-baited arm, (2) number of working memory errors (WMEs), i.e. reentries into an already visited baited arm, (3) number of total entries to complete the test.

\section{Preparation of brain samples}

Twenty-four hours after the RAM test, mice were decapitated under anesthesia and the brain tissues were removed quickly. After washed with normal saline over the ice, brains were immediately stored at $-80{ }^{\circ} \mathrm{C}$ until assay.

\section{Measurement of oxidative stress}

To evaluate the effect of IRN on oxidative stress status, the levels of malondialdehyde (MDA) and glutathione (GSH) and the activities of superoxide dismutases (SOD) and catalase (CAT) were measured. For these biochemical analyses, $10 \%(\mathrm{w} / \mathrm{v})$ brain homogenate was prepared in $0.9 \%$ sterile normal saline using a potter homogenizer at a speed of $1200 \mathrm{rpm}$. The homogenate was centrifuged at $3000 \times g$ for $10 \mathrm{~min}$ at $4{ }^{\circ} \mathrm{C}$ and then the supernatant

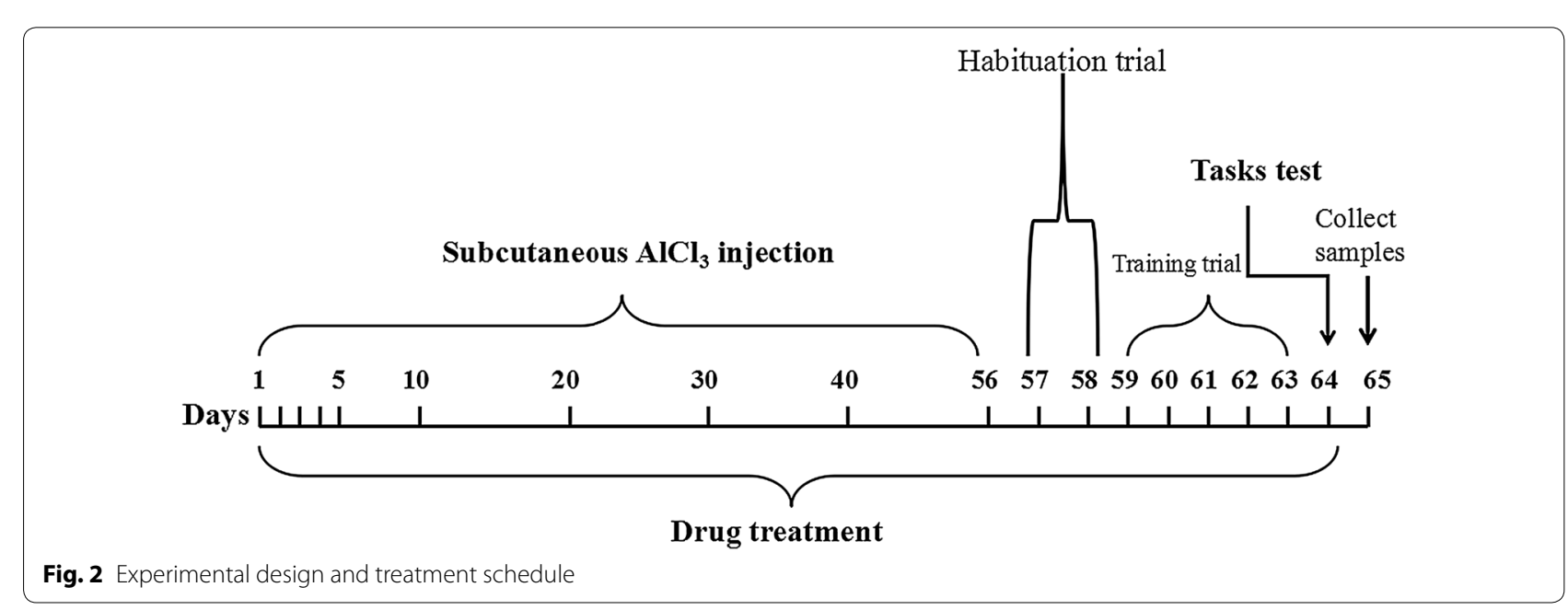


was collected. The supernatant was separated and tested with SOD assay kit, GSH assay kit, CAT assay kit and MDA assay kit (Cat. A001-3, A006-1, A007-1 and A0031, respectively, Nanjing Jiancheng Institute, Jiangsu, China) following the manufacturer's protocols. CAT activity was determined by the rate of decomposition of $1 \mu \mathrm{M} \mathrm{H}_{2} \mathrm{O}_{2}$ and expressed as U/mgprot. SOD activity was determined by the amount of enzyme required to produce $50 \%$ inhibition and expressed as $\mathrm{U} / \mathrm{mgprot}$. Reduced GSH was determined based on the formation of a yellow colored complex with 5,5'-dithiobis-(2-nitrobenzoic acid) (DTNB) and the level of GSH in tissue was expressed as mgGSH/gprot. Reduced MDA was determined based on the formation of a red colored complex with thiobarbituric acid (TBA) and the level of MDA in tissue was expressed as $\mathrm{nmol} / \mathrm{mgprot}$. All samples were measured in duplicate.

\section{Measurement of the activities of acetylcholinesterase (AChE) and butyrylcholinesterase (BuChE)}

The activities of $\mathrm{AChE}$ and $\mathrm{BuChE}$ in the brain tissues were examined. At first, 10\% (w/v) brain homogenate was prepared in $0.9 \%$ sterile normal saline using a potter homogenizer at a speed of $1200 \mathrm{rpm}$. The homogenate was centrifuged at $3000 \times g$ for $10 \mathrm{~min}$ at $4{ }^{\circ} \mathrm{C}$ and then the supernatant was collected. The supernatant was separated and tested with the AChE assay kit and BuChE assay kit (Cat. A024 and A025, respectively, Nanjing Jiancheng Institute, Jiangsu, China) following the manufacturer's instructions. The activities of $\mathrm{AChE}$ and $\mathrm{BuChE}$ were determined based on the formation of Sym-Trinitrobenzene (TNB), which is a yellow colored complex, and the results were both expressed as $\mathrm{U} / \mathrm{mg}$ protein. All samples were measured in duplicate.

\section{Western blotting analysis}

For preparation of whole cell protein lysate, the brain tissues were homogenized in RIPA lysis buffer $(50 \mathrm{mM}$ Tris- $\mathrm{HCl}$ (pH 8.0), $150 \mathrm{mMNaCl}, 1 \% \mathrm{NP}-40,0.1 \%$ SDS, $0.5 \%$ sodium deoxycholate and $1 \%$ Protease/Phosphatase Inhibitor Cocktail) (Cell Signaling Technology, USA) for $30 \mathrm{~min}$ on ice, then centrifuged at $12,000 \mathrm{rpm}$ at $4{ }^{\circ} \mathrm{C}$, and then the supernatant was collected. Protein concentrations were determined using Bradford method with protein assay dye reagent (Bio-Rad, USA). Equal amounts of protein of different samples were separated by sodium dodecyl sulfate polyacrylamide gel electrophoresis (SDSPAGE), and then transferred to PVD membranes. After blocked with $5 \%(\mathrm{w} / \mathrm{v})$ non-fat milk in TBS-T $(50 \mathrm{mM}$ Tris, $150 \mathrm{mM} \mathrm{NaCl}$ and $0.1 \%$ Tween-20, $\mathrm{pH} 7.4$ ) at room temperature for $2 \mathrm{~h}$, the PVD membranes were incubated overnight at $4{ }^{\circ} \mathrm{C}$ in NF- $\mathrm{kB}$ p65 (p65), phospho-NF- $\mathrm{kB}$

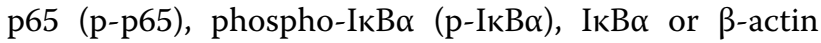

primary antibody (1:1000, Cell Signaling Technology, \#6956S, 3033S, 2859S, 9242S or 3700S, respectively). Rinsed with TBS-T for $5 \mathrm{~min} \times 3$ times, the PVD membranes were then incubated with secondary antibody for $2 \mathrm{~h}$ at room temperature, and then rinsed again with TBS-T for $5 \mathrm{~min} \times 3$ times. The protein bands were visualized by the ECL western blotting detection reagents (Amersham Biosciences, Buckinghamshire, UK). The intensity of each band was analyzed using Image J software (NIH Image, MD, USA).

\section{Statistical analysis}

All data were presented as the mean \pm standard error of the mean (SEM). Multiple group comparisons were performed using one-way analysis of variance (ANOVA) followed by Post-hoc Dunnett's test to detect inter-group differences. GraphPad Prism software (Version 5, GraphPad Software, Inc., CA, USA) was used to perform the statistical analysis. A difference was considered statistically significant when the $p<0.05$.

\section{Results}

\section{IRN ameliorated the cognitive deficits induced by $\mathrm{AlCl}_{3}$} in mice

After 7 days of training, the mice were subjected to working and reference memory tasks. Figure 3a shows the effect of IRN on the number of total entries to complete the maze. The results showed that $\mathrm{AlCl}_{3}+$ vehicle group markedly increased the number of total entries when compared with the control group $(\mathrm{F}(4,33)=4.694$, $p<0.01)$, while treatment with IRN $(40 \mathrm{mg} / \mathrm{kg})$ significantly decreased the number of total entries when compared with the $\mathrm{AlCl}_{3}+$ vehicle group $(p<0.01)$. Donepezil $(5 \mathrm{mg} / \mathrm{kg})$ treatment also decreased the number of total entries $(p<0.05)$ when compared with the $\mathrm{AlCl}_{3}+$ vehicle group.

The effects of IRN on reference memory errors (RMEs) and the working memory errors (WMEs) were shown in Fig. 3b, c, respectively. The results showed that $\mathrm{AlCl}_{3}$ plus vehicle group elevated the RMEs $(\mathrm{F}(4,33)=3.895$, $p<0.05)$ and WMEs $(\mathrm{F}(4,33)=4.416, p<0.01)$ to complete the task when compared with the control group, while treatment with IRN $(40 \mathrm{mg} / \mathrm{kg})$ significantly reduced the RMEs $(p<0.05)$ and WMEs $(p<0.01)$ when compared with the $\mathrm{AlCl}_{3}+$ vehicle group. Donepezil $(5 \mathrm{mg} / \mathrm{kg})$ treatment also significantly reduced the RMEs $(p<0.05)$ and WMEs $(p<0.05)$ when compared with the $\mathrm{AlCl}_{3}+$ vehicle group. On the other hand, IRN treatment at dosage of $20 \mathrm{mg} / \mathrm{kg} /$ day showed no significant difference in the number of the total entries $(p>0.05)$, RMEs $(p>0.05)$ or WMEs $(p>0.05)$ when compared with the $\mathrm{AlCl}_{3}+$ vehicle group. 

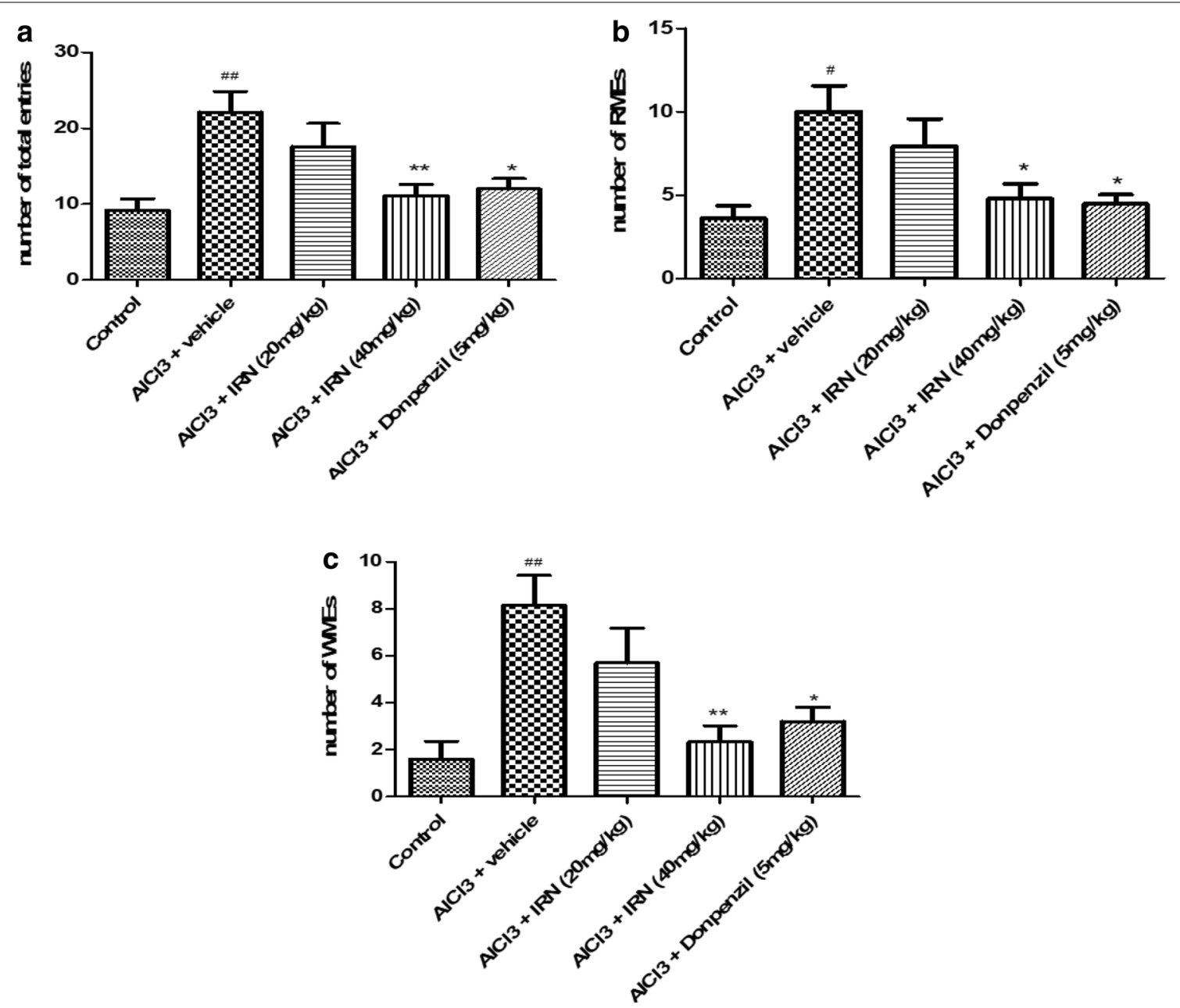

Fig. 3 Effects of IRN on spatial learning and memory of mice as evaluated by the RAM test after 7 days of training. The total entrances to complete the task (a), the reference memory errors (RMEs) (b), and the working memory errors (WMEs) (c). Data were expressed as mean $\pm S E M s(n=6-10)$. ${ }^{\#} p<0.05$ and ${ }^{\# \#} p<0.01$ compared with the control group; ${ }^{*} p<0.05$ and ${ }^{* *} p<0.01$ compared with the $\mathrm{AlCl}_{3}+$ vehicle group

\section{IRN reduced the oxidative damage induced by $\mathrm{AICl}_{3}$ in mice}

The oxidative stress of brain tissue was assessed by measuring the level of MDA, a lipid peroxidation product (Fig. 4a), and antioxidants including GSH (Fig. 4b), SOD (Fig. 4c) and CAT (Fig. 4d).

Figure 4a showed that the MDA level was significantly higher in $\mathrm{AlCl}_{3}$ + vehicle group than the control group $(\mathrm{F}(4,34)=6.585, p<0.05]$, while treatment with IRN $(40 \mathrm{mg} / \mathrm{kg})$ significantly decreased the MDA level when compared with the $\mathrm{AlCl}_{3}+$ vehicle group $(p<0.05)$. Donepezil $(5 \mathrm{mg} / \mathrm{kg})$ treatment also inhibited the MDA level when compared with $\mathrm{AlCl}_{3}+$ vehicle group $(p<0.01)$.

As shown in Fig. 4b, the GSH level was significantly lower in the $\mathrm{AlCl}_{3}+$ vehicle group than the control group $(\mathrm{F}(4,34)=4.06, p<0.01)$, while treatment with IRN (40 mg/kg) significantly increased the GSH level when compared with the $\mathrm{AlCl}_{3}+$ vehicle group $(p<0.05)$. Donepezil $(5 \mathrm{mg} / \mathrm{kg})$ treatment also increased the $\mathrm{GSH}$ level when compared with the $\mathrm{AlCl}_{3}+$ vehicle group $(p<0.01)$.

Figure $4 \mathrm{c}$ showed that the SOD activity was significantly suppressed in the $\mathrm{AlCl}_{3}+$ vehicle group when compared with the control group $(\mathrm{F}(4,34)=5.571$, $p<0.001)$, while treatment with IRN $(40 \mathrm{mg} / \mathrm{kg})$ significantly increased the SOD activity when compared with the $\mathrm{AlCl}_{3}+$ vehicle group $(p<0.05)$. Donepezil $(5 \mathrm{mg}$ / $\mathrm{kg}$ ) treatment also increased the SOD activity when compared with the $\mathrm{AlCl}_{3}+$ vehicle group $(p<0.05)$.

Moreover, Fig. 4d showed that the CAT activity was significantly decreased in the $\mathrm{AlCl}_{3}+$ vehicle group when compared with the control group ( $\mathrm{F}$ (4, 

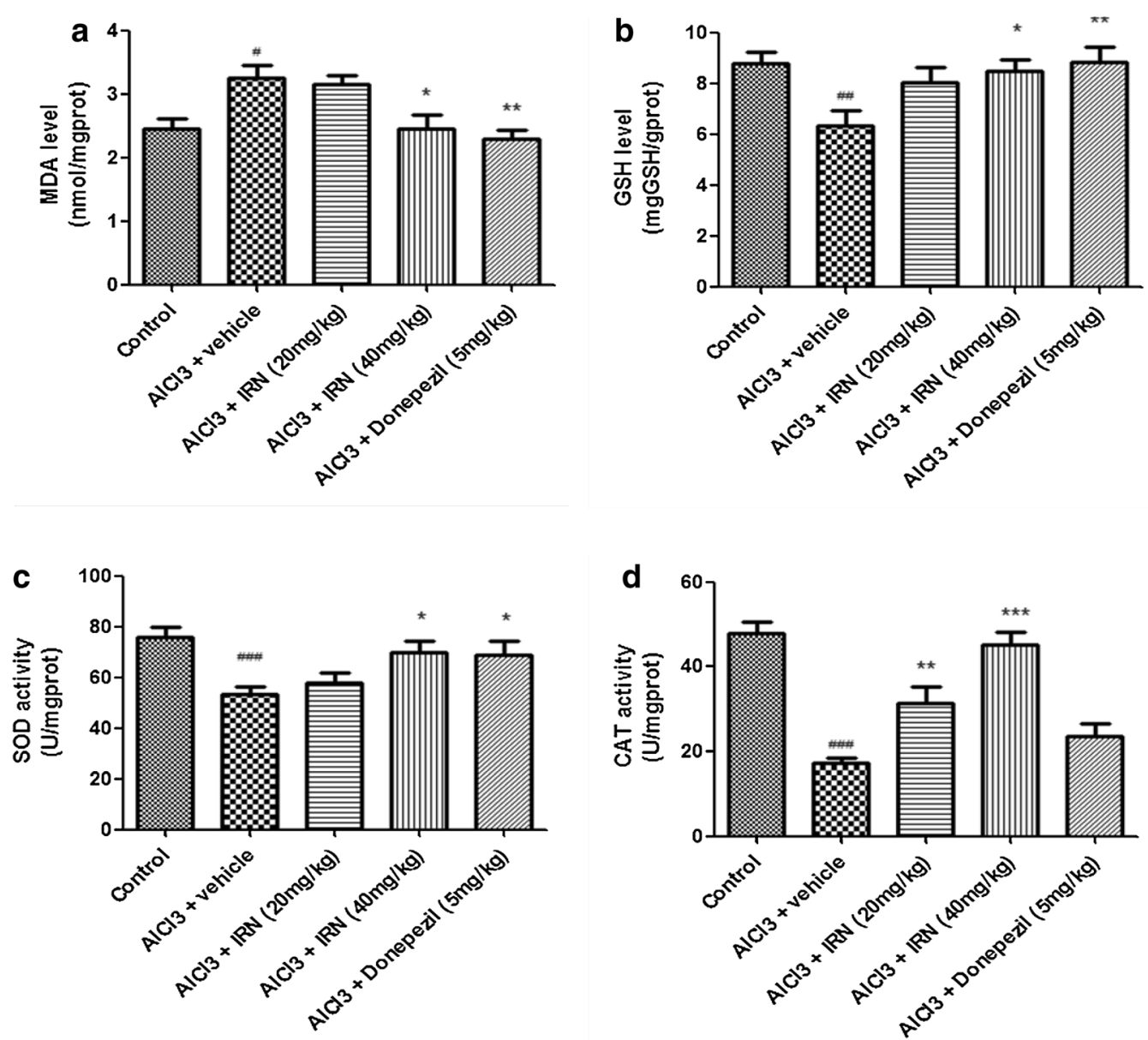

Fig. 4 Effect of IRN treatment on the levels of MDA (a) and GSH (b) and the activities of SOD (c) and CAT (d) in the brains of $\mathrm{AlCl}_{3}$-treated mice. Data were expressed as mean \pm SEMs $(n=6-9)$. ${ }^{\#} p<0.05,{ }^{\# \#} p<0.01$ and ${ }^{\# \#} p<0.001$ compared with the control group; ${ }^{*} p<0.05$, ${ }^{*} p<0.01$ and *** $p<0.001$ compared with the $\mathrm{AlCl}_{3}+$ vehicle group

$34)=18.29, p<0.001$ ), while the treatment with IRN (20 and $40 \mathrm{mg} / \mathrm{kg}$ ) significantly increased the CAT activity when compared with the $\mathrm{AlCl}_{3}+$ vehicle group, $(p<0.01$ and $p<0.001$, respectively). However, donepezil $(5 \mathrm{mg} / \mathrm{kg})$ treatment did not show significant effect $(p>0.05)$ on the activity of CAT.

\section{IRN inhibited the cholinesterase activity in the brain of $\mathrm{AlCl}_{3}$-treated mice}

The effect of IRN on cholinesterase activity was assessed by measuring the activities of AChE (Fig. $5 \mathrm{a}$ ) and BuChE (Fig. 5b). Figure 5a showed that the AChE activity was significantly increased in the $\mathrm{AlCl}_{3}+$ vehicle group when compared with the control group $(\mathrm{F}(4,34)=4.144$, $p<0.05$, while treatment with IRN $(40 \mathrm{mg} / \mathrm{kg})$ significantly decreased the $\mathrm{AChE}$ activity when compared with the $\mathrm{AlCl}_{3}+$ vehicle group $(p<0.05)$. Donepezil $(5 \mathrm{mg} / \mathrm{kg})$ treatment also decreased the AChE activity when compared with the $\mathrm{AlCl}_{3}+$ vehicle group $(p<0.01)$. On the other hand, Fig. $5 \mathrm{~b}$ showed that the BuChE activity was significantly increased in the $\mathrm{AlCl}_{3}+$ vehicle group when compared with the control group, but treatment with IRN (20 and $40 \mathrm{mg} / \mathrm{kg}$ ) did not show significant effect on $\mathrm{BuChE}$ activity when compared with the $\mathrm{AlCl}_{3}+$ vehicle group ( $p>0.05$ for both). Donepezil $(5 \mathrm{mg} / \mathrm{kg}$ ) treatment markedly decreased the BuChE activity when compared with the $\mathrm{AlCl}_{3}+$ vehicle group $(p<0.05)$.

\section{IRN inhibited the activation of NF-KB signaling pathway in the brain of $\mathrm{AlCl}_{3}$-treated mice}

Effect of IRN treatment on the NF- $\mathrm{kB}$ signaling pathway in the brain tissues of $\mathrm{AlCl}_{3}$-treated mice were determined by Western blotting (Figs. 6a and 7a). Relative density of $\mathrm{p}-\mathrm{p} 65 / \mathrm{p} 65$ and $\mathrm{p}-\mathrm{I} \kappa \mathrm{B} \alpha / \mathrm{I} \mathrm{K} \mathrm{B} \alpha$ were shown in Figs. $6 \mathrm{~b}$ and $7 \mathrm{~b}$, respectively. Figure $6 \mathrm{~b}$ showed that the relative density of $\mathrm{p}-\mathrm{p} 65 / \mathrm{p} 65$ was significantly increased in the $\mathrm{AlCl}_{3}+$ vehicle group when compared with the control group $(\mathrm{F}(4,34)=9.896, p<0.001]$, 

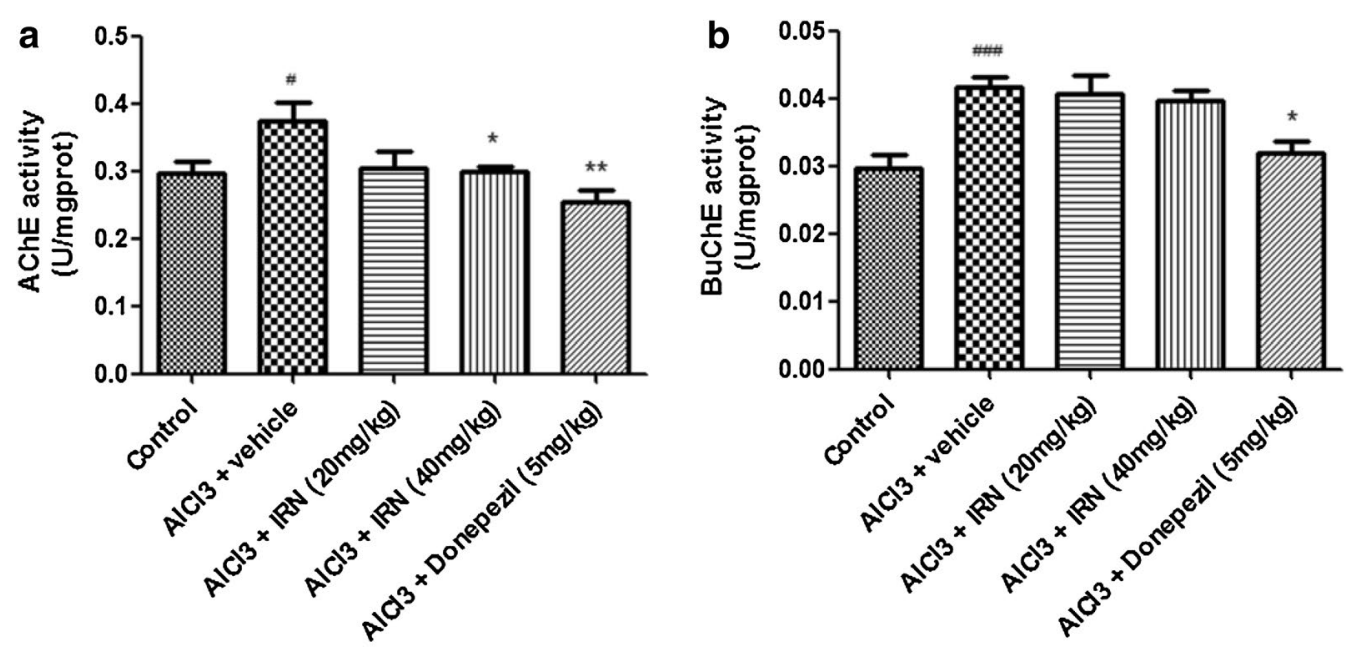

Fig. 5 Effect of IRN treatment on the activities of AChE (a) and BuChE (b) in the brain of the $\mathrm{AlCl}_{3}$-treated mice. Data were expressed as mean \pm SEMs $(n=6-9) .{ }^{\#} p<0.05$ and ${ }^{\# \# \#} p<0.001$ compared with the control group; ${ }^{*} p<0.05$ and ${ }^{* *} p<0.01$ compared with the $\mathrm{AlCl}_{3}+$ vehicle group

while treatment with IRN (20 and $40 \mathrm{mg} / \mathrm{kg})$ significantly decreased the relative density of p-p65/p65 when compared with the $\mathrm{AlCl}_{3}+$ vehicle group $(p<0.01$ and $p<0.01$, respectively). Donepezil $(5 \mathrm{mg} / \mathrm{kg})$ treatment also decreased the relative density of $\mathrm{p}-\mathrm{p} 65 / \mathrm{p} 65$ when compared with $\mathrm{AlCl}_{3}+$ vehicle group $(p<0.01)$. On the other hand, Fig. $7 \mathrm{~b}$ showed that the relative density of $\mathrm{p}-\mathrm{I} \kappa \mathrm{B} \alpha / \mathrm{I} \kappa \mathrm{B} \alpha$ was significantly increased in the $\mathrm{AlCl}_{3}+$ vehicle group when compared with the control group $(\mathrm{F}(4,23)=7.125, p<0.001)$, while the treatment with IRN (20 and $40 \mathrm{mg} / \mathrm{kg}$ ) significantly decreased the relative density of $\mathrm{p}-\mathrm{p} 65 / \mathrm{p} 65$ when compared with the $\mathrm{AlCl}_{3}+$ vehicle group $(p<0.01$ and $p<0.01$, respectively).
Donepezil $(5 \mathrm{mg} / \mathrm{kg})$ treatment also decreased the relative density of p-p65/p65 when compared with the $\mathrm{AlCl}_{3}+$ vehicle group $(p<0.01)$.

\section{Discussion}

The present study investigated the neuroprotective effects of IRN on the $\mathrm{AlCl}_{3}$-induced cognitive impairment in mice. In our experiment, radial arm maze test was conducted to assess the spatial learning and memory functions of the mice. The results showed that $\mathrm{AlCl}_{3}$ treatment impaired the spatial learning and memory functions of the mice, enhanced the oxidative stress,
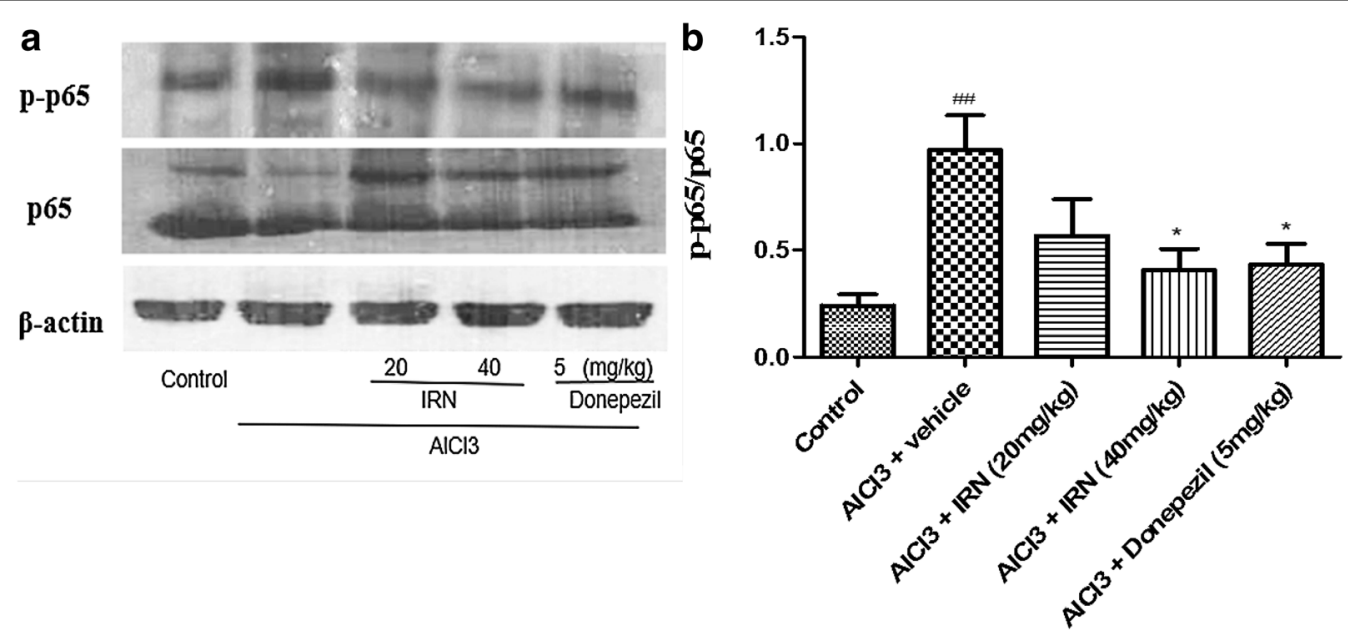

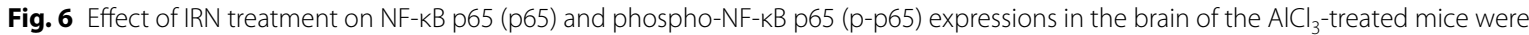
determined by Western blotting (a). The relative density of p-p65/p65 (b) were analyzed by Image J. software. Data were expressed as mean \pm SEMs $(n=4-6) . \# \#>0.01$ compared with the control group; ${ }^{* *} p<0.05$ compared with the $\mathrm{AlCl}_{3}+$ vehicle group 

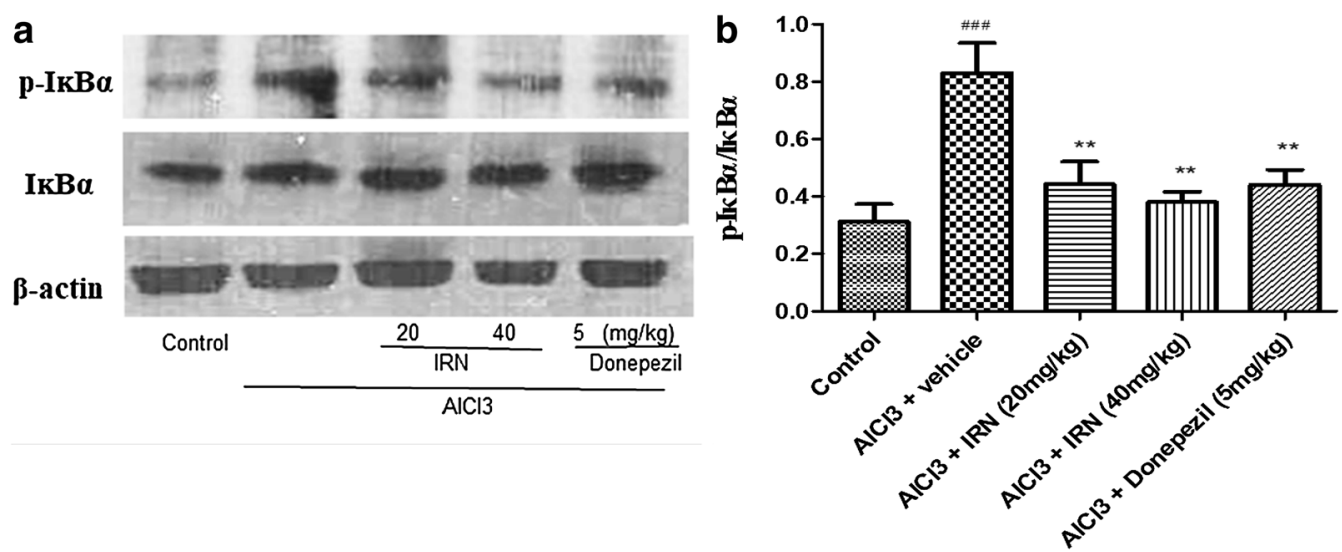

Fig. 7 Effect of IRN treatment on $\mid \mathrm{KBa}$ and phospho-IKBa $\left(\mathrm{p}-\mathrm{I}_{\mathrm{KBa}}\right)$ expressions in the brain of the $\mathrm{AlCl}_{3}$-treated mice were determined by Western blotting (a). The relative density of $\mathrm{p}-\mathrm{I} \mathrm{KBa} / \mathrm{I} \mathrm{KBa}(\mathbf{b})$ were analyzed by Image J. software. Data were expressed as mean $\pm \operatorname{SEMs}(n=4-6)$. \#\#\# $p<0.001$ compared with the control group; ${ }^{* *} p<0.01$ compared with the $\mathrm{AlCl}_{3}+$ vehicle group

damaged the cholinergic system, and activated the NF-kB signaling pathway in the brain. On the other hand, treatment with IRN significantly reversed these changes induced by $\mathrm{AlCl}_{3}$ in mice, suggesting that IRN is a potential anti-AD agent for the treatment of AD.

So far, several cognitive domains found disrupted in AD have been modeled, and the two most extensively modeled and assessed domains are working memory and reference memory [28]. The RAM test was firstly introduced by Olton in 1976 [29]. It is one of the most commonly used animal behavioral tasks to assess working memory and reference memory, just as the Morris water maze [28]. In the RAM test, the number of total entries to complete the maze is considered as an overall measure of learning and memory [30]. As previously reported, a reference memory error was noted if an animal enters an arm that never contained a food reward, and a working memory error was noted if an animal enters a baited arm previously visited during the same trial [31, 32]. The higher numbers of RMEs and WMEs are recorded, the worse the reference memory and working memory are indicated. In the present study, $\mathrm{AlCl}_{3}+$ vehicle group showed significant increases in RMEs and WMEs to complete the task when compared with the control group, indicating that $\mathrm{AlCl}_{3}$ induced significant impairments on reference memory and working memory in mice. IRN treatment reduced both of RMEs and WMEs when compared with the $\mathrm{AlCl}_{3}$ + vehicle group, indicating that IRN could improve the reference memory and working memory.

It has been reported that chronic exposure to aluminum at a dose of $1.6 \mathrm{mg} / \mathrm{kg} /$ day, equivalent to the high end of the human dietary aluminum range, could lead to oxidative damage in the brain and cause AD-like behaviors in rats [12]. However, short exposure to aluminum could only lead to transient memory impairment in Morris water maze [33], and low doses of aluminum may fail to observe impairment of performance in RAM test [34]. Therefore, to ensure well-established biochemical and behavioral deficits, suitable duration and dose of $\mathrm{AlCl}_{3}$ should be selected. In our preliminary study, we found that about $70 \%$ mice died after treatment with $\mathrm{AlCl}_{3}$ at a dose of $100 \mathrm{mg} / \mathrm{kg} /$ day for 8 consecutive weeks (data not shown), suggesting that the dose of $\mathrm{AlCl}_{3}$ $(100 \mathrm{mg} / \mathrm{kg} / \mathrm{day})$ is too high. Therefore, in this present study, the dosage of $50 \mathrm{mg} / \mathrm{kg} /$ day of $\mathrm{AlCl}_{3}$ was used to induce the $\mathrm{AD}$-like behaviors and the duration of exposure was set for 8 weeks.

Oxidative stress is an imbalance state between the generation and detoxification of reactive oxygen species (ROS) products [35]. It could be assessed by measuring peroxidation products of ROS, such as lipid peroxidation, and antioxidant levels [35]. Oxidative stress in human increases with age [36]. Oxidative stress is known to play an important role in the initiation of AD [37]. High lipid peroxidation and decreased antioxidant defenses are found to be presented in mild cognitive impairment (MCI) patients, implying that oxidative stress represents a sign of AD pathology and could be an early event in the progression of MCI to $\mathrm{AD}$ [38]. In addition, oxidative damage is found not only in the vulnerable neurons of brain affected in this disease [39], but also throughout the body in AD patients [40]. Moreover, many line of evidence showed that oxidative stress could cause marked accumulation of $A \beta$ and phosphorylated tau protein in vitro and in vivo [41-43], which are considered to be the two main causal factors for AD. Given its close correlation, oxidative stress is even considered as a primary 
progenitor of $\mathrm{AD}$, not merely an epiphenomenon. Thus, novel drug with anti-oxidative effects could be a preventative cure for the disease [44]. The present study showed that in the brains of the $\mathrm{AlCl}_{3}+$ vehicle mice, the MDA level was significantly higher, while the activities of SOD and CAT and the GSH level were significantly lower than control group, suggesting that $\mathrm{AlCl}_{3}$ was able to induce high oxidative stress in mice. However, IRN treatment decreased this oxidative damage induced by $\mathrm{AlCl}_{3}$, indicating it is a potential antioxidant for AD. In the present study, donepezil did not show effect on CAT activity. Donepezil is known as cholinesterase inhibitor for $\mathrm{AD}$ treatment. Although there is evidence that donepezil also affected the levels of GSH and MDA [45], but no evidence showed donepezil had effect on the activity of CAT, which is an antioxidant. Donepezil may suppress oxidative stress by affecting the levels of GSH and MDA, as well as the activity of SOD, but not CAT activity.

As is known, the cholinergic pathway in basal forebrain plays an important role in mnemonic processes, memory, conscious awareness and attention [46]. Evidence showed acetylcholine involved in spatial information processing [47]. Degeneration and loss of cholinergic neurons in the basal forebrain nuclei cause deficit of acetylcholine, then cause disturbances in presynaptic cholinergic terminals in the hippocampus and neocortex, leading to memory disturbances and other cognitive symptoms associated with $\mathrm{AD}$ [48]. Thus, acetylcholine is considered as an important neurotransmitter for memory in brains, and preventing the decrease of the level of acetylcholine may be an effective treatment strategy for AD. AChE is the primary cholinesterase that breaks down acetylcholine in the body, and activation of $\mathrm{AChE}$ will aggravate the deficit of acetylcholine. Cholinesterase inhibitors, such as donepezil, delay the breakdown of acetylcholine via suppressing the activity of $\mathrm{AChE}$, more or less restore the cortical concentration of acetylcholine, and thus temporarily ameliorate the cognitive symptoms of $\mathrm{AD}$ [49]. Aluminum exposure was reported to be associated with impairment in the cholinergic system as a strong activator of AChE [50]. Our results showed that activity of $\mathrm{AChE}$ in the brain of $\mathrm{AlCl}_{3}+$ vehicle group was significantly higher than control group. On the other hand, IRN treatment significantly inhibited the AChE activity, but not BuChE. Although both of $\mathrm{AChE}$ and $\mathrm{BuChE}$ are cholinesterase, they differ in location, substrate specificity and kinetics [51]. IRN showed effect on AChE activity but not BuChE activity, indicating it is a potential selective $\mathrm{AChE}$ inhibitor for treatment of $\mathrm{AD}$.

NF- $\kappa B$, a collective name for inducible dimeric transcription factors, is involved in activation of many genes in response to infections, inflammation and other stressful situations requiring rapid reprogramming of gene expression [52]. Evidence showed that NF- $\mathrm{KB}$ is involved in brain function, particularly following injury and in neurodegenerative conditions such as $\mathrm{AD}$, and is activated in neurons in certain regions of the brain during neurogenesis [53]. Furthermore, studies suggested that NF- $\kappa B$ plays a critical role in initiating and regulating the inflammation or oxidative stress in AD [54]. Increase of NF- $\mathrm{kB}$ p 65 level could be found both in the temporal and frontal cortices of human $\mathrm{AD}$ brains [55]. It is now known that NF- $\mathrm{KB}$ preexists in the cytoplasm of cells in an inactive form bound to the inhibitor, I $\mathrm{K} B$, as NF- $\mathrm{kB}$ :I $\kappa \mathrm{B}$ complex [56]. Under certain circumstances, stimulation of cells by diverse inducers causes phosphorylation of cyto-

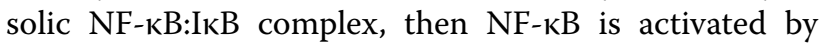
phosphorylation of $\mathrm{I} \kappa \mathrm{B} \alpha$ and released to the nucleus [57, 58]. In the nucleus, NF- $\mathrm{kB}$ dimers bind to target DNA elements and activate transcription of genes encoding proteins involved with innate immune or inflammation responses [59]. Thus, inhibition of the phosphorylation of IкB $\alpha$ and NF-кB p65 may be a valuable drug target to reduce stressful damage for $\mathrm{AD}$ patients. The most abundant form of the NF- $\mathrm{kB}$ family is the heterodimeric p65p50 complex [57] and the best-characterized ІкB proteins is IкB $[56]$. Our result revealed that the levels of phosphorylation of NF-kB p65 and IкB $\alpha$ were significantly accentuated in the brain of $\mathrm{AlCl}_{3}+$ vehicle mice. IRN treatment decreased the phosphorylation of NF- $\mathrm{kB}$ p65 and IKB $\alpha$, suggesting that IRN inhibited the activation of $\mathrm{NF}-\mathrm{KB}$ signaling pathway induced by $\mathrm{AlCl}_{3}$ in mice.

\section{Conclusions}

Our experimental results for the first time demonstrated that IRN alleviated learning and memory impairments induced by $\mathrm{AlCl}_{3}$ in mice. The protective effect of IRN against $\mathrm{AlCl}_{3}$-induced cognitive deficits is probably mediated, at least in part, through inhibiting the AChE activity and reducing the oxidative damage of brain tissue via inhibiting the activation of NF- $\mathrm{KB}$ signaling pathway. These results further confirmed the in vivo anti-AD effect of IRN and suggested that IRN exhibits multi-target therapeutic potential for the treatment of AD. It was concluded that IRN could protect the learning and memory function. Further investigations are needed to reveal the anti-AD effect mechanisms of IRN.

\section{Additional file}

Additional file 1. Minimum standards of reporting checklist.

Abbreviations

AChE: acetylcholinesterase; AD: Alzheimer's disease; $\mathrm{AlCl}_{3}$ : aluminum chloride; BuChE: butyrylcholinesterase; CAT: catalase; DTNB: 5,5'-dithiobis 
(2-nitrobenzoic acid); CMC-Na: sodium carboxymethyl cellulose; GSH: glutathione; IRN: isorhynchophylline; MDA: malondialdehyde; MCl: mild cognitive impairment; NF-Kb: nuclear factor kappa B; p-IkBa: phospho-IkBa; p-p65: phospho-NF-KB p65; RAM: radial arm maze; ROS: reactive oxygen species; RMEs: reference memory errors; SDS-PAGE: sodium dodecyl sulfate polyacrylamide gel electrophoresis; SEM: standard error of the mean; SOD: superoxide dismutases; TBA: thiobarbituric acid; TNB: Sym-Trinitrobenzene; WMEs: working memory errors.

\section{Authors' contributions}

LZX and XYF conceived and designed the study. LHQ performed the in vivo studies and collected the data. LHQ and XYF analyzed the data. LHQ wrote the manuscript. LZX, XYF, ZGQ and ISP revised the manuscript. All authors read and approved the final manuscript.

\section{Author details}

${ }^{1}$ School of Chinese Medicine, Faculty of Medicine, The Chinese University of Hong Kong, Hong Kong, SAR, People's Republic of China. ${ }^{2}$ Brain Research Centre, School of Chinese Medicine, Faculty of Medicine, The Chinese University of Hong Kong, Hong Kong, SAR, People's Republic of China. ${ }^{3}$ Department of Neurology, The Second Affiliated Hospital and Yuying Children's Hospital of Wenzhou Medical University, Wenzhou, Zhejiang Province, People's Republic of China. ${ }^{4}$ Institute of Integrative Medicine, Faculty of Medicine, The Chinese University of Hong Kong, Hong Kong, SAR, People's Republic of China.

\section{Acknowledgements}

Not applicable.

\section{Competing interests}

The authors declare that they have no competing interests.

\section{Availability of data and materials}

I agree to share my data and materials.

\section{Consent for publication}

Not applicable.

\section{Ethics approval and consent to participate}

The experimental procedures were approved by Department of Health, The Government of the Hong Kong Special Administrative Region [Ref. No. (15-853) in DH/HA\&P/8/2/1 Pt.54], and conformed to the Guidelines of the Principles of Laboratory Animal Care (NIH Publication No. 80-23, revised 1996).

\section{Fundings}

This work was supported by the General Research Fund from Research Grants Council of Hong Kong (Project No. 14110814) and the CUHK Direct Grant (Project No. 2015.1.081).

\section{Publisher's Note}

Springer Nature remains neutral with regard to jurisdictional claims in published maps and institutional affiliations.

Received: 20 February 2018 Accepted: 2 June 2018 Published online: 14 June 2018

\section{References}

1. Lecanu L, Papadopoulos V. Modeling Alzheimer's disease with nontransgenic rat models. Alzheimers Res Ther. 2013;5:17.

2. Brookmeyer R, Johnson E, Ziegler-Graham K, Arrighi HM. Forecasting the global burden of Alzheimer's disease. Alzheimers Dement. 2007;3:186-91.

3. Apter JT, Shastri K, Pizano K. Update on disease-modifying/preventive therapies in Alzheimer's disease. CurrGeriatr Rep. 2015:4:312-7.

4. Rygiel K. Novel strategies for Alzheimer's disease treatment: An overview of anti-amyloid beta monoclonal antibodies. Indian J Pharmacol. 2016;48:629.

5. Kumar A, Singh A, Ekavali. A review on Alzheimer's disease pathophysiology and its management: an update. Pharmacol Rep. 2015;2:195-203.
6. Honig LS, Vellas B, Woodward M, Boada M, Bullock R, Borrie M, Hager K, Andreasen N, Scarpini E, Liu-Seifert H, et al. Trial of Solanezumab for Mild Dementia Due to Alzheimer's Disease. N Engl J Med. 2018;4:321-30.

7. Priest N. The biological behaviour and bioavailability of aluminium in man, with special reference to studies employing aluminium-26 as a tracer: review and study update. J Environ Monit. 2004;6:375-403.

8. Kawahara M, Kato-Negishi M. Link between aluminum and the pathogenesis of Alzheimer's disease: the integration of the aluminum and amyloid cascade hypotheses. Int J Alzheimers Dis. 2011:2011:276393.

9. Walton J. Aluminum in hippocampal neurons from humans with Alzheimer's disease. Neurotoxicology. 2006;27:385-94.

10. Walton J. Functional impairment in aged rats chronically exposed to human range dietary aluminum equivalents. Neurotoxicology. 2009:30:182-93.

11. Yu L, Jiang R, Su Q, Yu H, Yang J. Hippocampal neuronal metal ion imbalance related oxidative stress in a rat model of chronic aluminum exposure and neuroprotection of meloxicam. Behav Brain Funct. 2014;10:6

12. Walton J. An aluminum-based rat model for Alzheimer's disease exhibits oxidative damage, inhibition of PP2A activity, hyperphosphorylated tau, and granulovacuolar degeneration. J InorgBiochem. 2007:101:1275-84.

13. Prakash D, Sudhandiran G. Dietary flavonoid fisetin regulates aluminium chloride-induced neuronal apoptosis in cortex and hippocampus of mice brain. J NutrBiochem. 2015;26:1527-39.

14. Prakash A, Kumar A. Effect of N-Acetyl Cysteine against Aluminiuminduced Cognitive Dysfunction and Oxidative Damage in Rats. Basic ClinPharmacolToxicol. 2009;105:98-104.

15. Erazi H, Sansar W, Ahboucha S, Gamrani H. Aluminum affects glial system and behavior of rats. C R Biol. 2010;333:23-7.

16. Iwasaki K, Satoh-Nakagawa T, Maruyama M, Monma Y, Nemoto M, Tomita $\mathrm{N}$, Tanji H, Fujiwara H, Seki T, Fujii M. A Randomized, observer-blind, controlled trial of the traditional Chinese medicine Yi-Gan San for improvement of behavioral and psychological symptoms and activities of daily living in dementia. J Clin Psychiatry. 2005:66:248-52.

17. Watanabe H, Zhao Q, Matsumoto K, Tohda M, Murakami Y, Zhang SH, Kang TH, Mahakunakorn P, Maruyama Y, Sakakibara I. Pharmacological evidence for antidementia effect of Choto-san (Gouteng-san), a traditional Kampo medicine. PharmacolBiochemBehav. 2003;75:635-43.

18. Xian YF, Lin ZX, Mao QQ, Hu Z, Zhao M, Che CT, Ip SP. Bioassay-guided isolation of neuroprotective compounds from Uncaria rhynchophylla against beta-amyloid-induced neurotoxicity. Evid Based Complement Alternat Med. 2012;2012:802625.

19. Xian YF, Lin ZX, Zhao M, Mao QQ, Ip SP, Che CT. Uncaria rhynchophylla ameliorates cognitive deficits induced by D-galactose in mice. Planta Med. 2011;77:1977-83.

20. Kang TH, Murakami Y, Takayama H, Kitajima M, Aimi N, Watanabe H, Matsumoto K. Protective effect of rhynchophylline and isorhynchophylline on in vitro ischemia-induced neuronal damage in the hippocampus: putative neurotransmitter receptors involved in their action. Life Sci. 2004:76:331-43.

21. Xian YF, Lin ZX, Mao QQ, Chen JN, Su ZR, Lai XP, Ip PS. Isorhynchophylline protects $\mathrm{PC} 12$ cells against beta-amyloid-induced apoptosis via PI3K/Akt signaling pathway. Evid Based Complement Alternat Med. 2013:2013:163057.

22. Xian YF, Mao QQ, Wu JC, Su ZR, Chen JN, Lai XP, Ip SP, Lin ZX. Isorhynchophylline treatment improves the amyloid- $\beta$-induced cognitive impairment in rats via inhibition of neuronal apoptosis and tau protein hyperphosphorylation. J Alzheimers Dis. 2014;39:331-46.

23. Xian YF, Su ZR, Chen JN, Lai XP, Mao QQ, Cheng CH, Ip SP, Lin ZX. Isorhynchophylline improves learning and memory impairments induced by D-galactose in mice. Neurochem Int. 2014;76:42-9.

24. Ozaki Y. Pharmacological studies of indole alkaloids obtained from domestic plants, Uncaria rhynchophylla Miq. and Amsonia elliptica Roem. et Schult. Nihon YakurigakuZasshi. 1989; 94:17-26.

25. Abdel-Aal RA, Assi AA, Kostandy BB. Rivastigmine reverses aluminuminduced behavioral changes in rats. Eur J Pharmacol. 2011;659:169-76.

26. Crusio WE, Schwegler H, Brust I. Covariations Between Hippocampal Mossy Fibres and Working and Reference Memory in Spatial and Nonspatial Radial Maze Tasks in Mice. Eur J Neurosci. 1993;5:1413-20.

27. Foyet HS, Asongalem AE, Oben EK, Cioanca O, Hancianu M, Hritcu L. Effects of the methanolic extract of Vitellaria paradoxa stem bark against 
scopolamine-induced cognitive dysfunction and oxidative stress in the rat hippocampus. Cell MolNeurobiol. 2016;36:1139-49.

28. Webster SJ, Bachstetter AD, Nelson PT, Schmitt FA, Van Eldik LJ. Using mice to model Alzheimer's dementia: an overview of the clinical disease and the preclinical behavioral changes in 10 mouse models. Front Genet. 2014;5:88.

29. Olton DS, Samuelson RJ. Remembrance of places passed: Spatial memory in rats. J Exp Psychol Anim Behav Process. 1976;2:97.

30. Evola M, Hall A, Wall T, Young A, Grammas P. Oxidative stress impairs learning and memory in apoE knockout mice. PharmacolBiochemBehav. 2010;96:181-6.

31. Hashimoto M, Hossain S, Agdul H, Shido O. Docosahexaenoic acidinduced amelioration on impairment of memory learning in amyloid beta-infused rats relates to the decreases of amyloid beta and cholesterol levels in detergent-insoluble membrane fractions. Biochim Biophys Acta. 2005;1-3:91-8

32. Mhatre M, Nguyen A, Kashani S, Pham T, Adesina A, Grammas P. Thrombin, a mediator of neurotoxicity and memory impairment. Neurobiol Aging. 2004;6:783-93.

33. Jamil A, Mahboob A, Ahmed T. Ibuprofen targets neuronal pentraxins expresion and improves cognitive function in mouse model of $\mathrm{AlCl} 3-$ induced neurotoxicity. ExpTher Med. 2016;11:601-6.

34. Connor DJ, Jope RS, Harrell LE. Chronic, oral aluminum administration to rats: cognition and cholinergic parameters. PharmacolBiochemBehav. 1988;31:467-74

35. Wang X, Wang W, Li L, Perry G, Lee HG, Zhu X. Oxidative stress and mitochondrial dysfunction in Alzheimer's disease. BiochimBiophys Acta. 2014;1842:1240-7.

36. Li Z, Chen X, Lu W, Zhang S, Guan X, Li Z, Wang D. Anti-Oxidative Stress Activity Is Essential for Amanita caesarea Mediated Neuroprotection on Glutamate-Induced Apoptotic HT22 Cells and an Alzheimer's Disease Mouse Model. Int J Mol Sci. 2017;18:1623.

37. Nunomura A, Perry G, Aliev G, Hirai K, Takeda A, Balraj EK, Jones PK, Ghanbari $\mathrm{H}$, Wataya T, Shimohama S, et al. Oxidative damage is the earliest event in Alzheimer disease. J NeuropatholExp Neurol. 2001;60:759-67.

38. López N, Tormo C, De Blas I, Llinares I, Alom J. Oxidative stress in Alzheimer's disease and mild cognitive impairment with high sensitivity and specificity. J Alzheimers Dis. 2013;33:823-9.

39. Casadesus G, Smith MA, Basu S, Hua J, Capobianco DE, Siedlak SL, Zhu $X$, Perry G. Increased isoprostane and prostaglandin are prominent in neurons in Alzheimer disease. MolNeurodegener. 2007;2:2.

40. Torres LL, Quaglio NB, de Souza GT, Garcia RT, Dati LMM, Moreira WL, de Melo Loureiro AP, Smid J, Porto CS, de Campos Bottino CM. Peripheral oxidative stress biomarkers in mild cognitive impairment and Alzheimer's disease. J Alzheimers Dis. 2011;26:59-68.

41. Bonda DJ, Castellani RJ, Zhu X, Nunomura A, Lee HG, Perry G, Smith MA. A novel perspective on tau in Alzheimer's disease. Curr Alzheimer Res. 2011;8:639-42.

42. LaFerla FM, Green KN, Oddo S. Intracellular amyloid- $\beta$ in Alzheimer's disease. Nat Rev Neurosci. 2007;8:499-509.
43. Leuner K, Schütt T, Kurz C, Eckert SH, Schiller C, Occhipinti A, Mai S, Jendrach M, Eckert GP, Kruse SE. Mitochondrion-derived reactive oxygen species lead to enhanced amyloid beta formation. Antioxid Redox Signal. 2012;16:1421-33.

44. Bonda DJ, Wang X, Perry G, Nunomura A, Tabaton M, Zhu X, Smith MA. Oxidative stress in Alzheimer disease: A possibility for prevention. Neuropharmacology. 2010;59:290-4.

45. Saxena G, Singh SP, Agrawal R, Nath C. Effect of donepezil and tacrine on oxidative stress in intracerebral streptozotocin-induced model of dementia in mice. Eur J Pharmacol. 2008;3:283-9.

46. Terry AV Jr, Buccafusco JJ. The cholinergic hypothesis of age and Alzheimer's disease-related cognitive deficits: recent challenges and their implications for novel drug development. J Pharmacol Exp Ther. 2003;3:821-7.

47. Deiana S, Platt B, Riedel G. The cholinergic system and spatial learning. Behav Brain Res. 2011;2:389-411.

48. Whitehouse PJ, Price DL, Clark AW, Coyle JT, DeLong MR. Alzheimer disease: evidence for selective loss of cholinergic neurons in the nucleus basalis. Ann Neurol. 1981;10:122-6.

49. Blennow K, de Leon MJ, Zetterberg H. Alzheimer's disease. Lancet. 2006;368:387-403.

50. Bilkei-Gorzo A. Neurotoxic effect of enteral aluminium. Food ChemToxicol. 1993:31:357-61.

51. Greig NH, Utsuki T, Yu Q, Zhu X, Holloway HW, Perry T, Lee B, Ingram DK, Lahiri DK. A new therapeutic target in Alzheimer's disease treatment: attention to butyrylcholinesterase. Curr Med Res Opin. 2001;3:159-65.

52. Karin $\mathrm{M}$, Ben-Neriah Y. Phosphorylation meets ubiquitination: the control of NF-KB activity. Annu Rev Immunol. 2000;18:621-63.

53. O'Neill LA, Kaltschmidt C. NF-kB: a crucial transcription factor for glial and neuronal cell function. Trends Neurosci. 1997;20:252-8.

54. Zou J, Cai PS, Xiong CM, Ruan JL. Neuroprotective effect of peptides extracted from walnut (Juglans Sigilata Dode) proteins on AB25-35induced memory impairment in mice. J Huazhong Univ Sci Technolog Med Sci. 2016;36:21-30.

55. Kitamura Y, Shimohama S, Ota T, Matsuoka Y, Nomura Y, Taniguchi T. Alteration of transcription factors NF-KB and STAT1 in Alzheimer's disease brains. Neurosci Lett. 1997;237:17-20.

56. Ghosh S, May MJ, Kopp EB. NF-KB and Rel proteins: evolutionarily conserved mediators of immune responses. Annu Rev Immunol. 1998;16:225-60.

57. Chen CH, Zhou W, Liu S, Deng Y, Cai F, Tone M, Tone Y, Tong Y, Song W. Increased NF-KB signalling up-regulates BACE1 expression and its therapeutic potential in Alzheimer's disease. Int I Neuropsychopharmacol. 2012;15:77-90

58. Kaltschmidt B, Uherek M, Volk B, Baeuerle PA, Kaltschmidt C. Transcription factor NF-kappaB is activated in primary neurons by amyloid beta peptides and in neurons surrounding early plaques from patients with Alzheimer disease. Proc Natl Acad Sci U S A. 1997:94:2642-7.

59. Baldwin AS Jr. The NF-KB and IKB proteins: new discoveries and insights, Annu Rev Immunol. 1996;14:649-81.

\footnotetext{
Ready to submit your research? Choose BMC and benefit from:

- fast, convenient online submission

- thorough peer review by experienced researchers in your field

- rapid publication on acceptance

- support for research data, including large and complex data types

- gold Open Access which fosters wider collaboration and increased citations

- maximum visibility for your research: over $100 \mathrm{M}$ website views per year
}

At BMC, research is always in progress.

Learn more biomedcentral.com/submissions 